\title{
On the Third Dagestani Campaign of Nadir Shah Afshar (1741): The Letters of Ibrahim of Urada
}

\author{
Timirlan Aytberov \\ Dagestan State University, Makhachkala
}

\begin{abstract}
The article presents the English translation with commentaries of three messages in Arabic by Ibrahim of Urada addressed to the people of Avaristan during the campaign of Nadir Shah to Dagestan. They provide important data elucidating the details of this poorly studied historical event that took place in the fall of 1741.
\end{abstract}

Keywords

Ibrahim of Urada (Uradinskij), Dagestani Campaign of Nadir Shah, Avaristan

Ibrahim (Ibrahim-haji or Ibrahim-efendi) of Urada (Uradinskij) is rightly considered the most authoritative jurist (faqih) of the 18th century Eastern Caucasus. Researchers characterise him also as a particularly active and successful military man, the chief organiser of the armed confrontation of the Dagestanis against the Iranian troops led by the famous military commander Nadir (Tahmāsp Qolī Khān) Afshar, known later as Nadir Shah (Sotavov 1991: 93; Gadžiev 1996: 161-163; Aytberov 2012: 226-228).

Ibrahim was a native of the ancient Avar settlement of Urada (Avar ГІурада), which was believed to have around 500 households in 1844 (Xašaev 1961: 17; Aytberov 2012: 10, 13). He descended from a local aristocratic family allegedly of Arab origin. In the 17th-18th centuries, many members of this family were hajis and Muslim scholars.

Ibrahim of Urada became famous both as a Muslim scholar (his writings in Arabic have survived to this day) ${ }^{1}$ and as a political and military

\footnotetext{
${ }^{1}$ He raised approximately the same issues of Dagestani life of the 18th century as his father Muhammad-haji, but he wrote about other matters as well (for more information, see Aytberov 2012: 96-205). 
figure. He wrote to Nadir Afshar, known as Taimaz Khan among the Dagestanis, the future Shah of Iran, a daring letter in 1735 in which there was such a phrase: we [the Dagestanis] will defeat... you. ${ }^{2}$

In 2016, I received copies of the three letters written by the hand of Ibrahim of Urada, most probably in 1741, from the late I. Kh. Butaev, a wellknown local historian from the Tidib village in Shamilskij district of the Republic of Dagestan. ${ }^{3}$ These documents, following below in the English translation, are important for elucidating the details of the Dagestani campaign of Nadir Shah undertaken in the fall of 1741. It should be noted that this campaign, which ended with the defeat of the Iranian army is very poorly addressed in Eastern, European and Russian sources of the 18 th century.

\section{LETTER I}

This letter is written with a reed (Avar myuIu) kalam, black ink (Avar. uлакъu), in naskh calligraphic style by Ibrahim-efendi on a sheet (15. 8 x 13 . $3 \mathrm{~cm}$ ) of white factory paper (Avar. кагzam) of Western European production. The number of the lines is 14 . Vowels and diacritic signs are partially marked. The Arabic letter lam with three points under it was used for the rendition of the Avar specific (lateral) sound $\mathcal{A}$. There is no seal as in the other two letters. Apparently, Ibrahim of Urada had not a personal seal, for he did not hold any official position within Gidatl (Avar Гьидалz), an Avar speaking district, ${ }^{4}$ the centre of which was the large village of Urada. On the margins of this letter there are pieces written in Arabic that are not relevant to the central text; these additions, made presumably after 1741, are excerpts from books on Islamic law popular in Dagestan (such as Anwar, Ibn Hajar, etc.).

\footnotetext{
${ }^{2}$ About this message and its copies, see Aytberov 2012: 110- 115 (in this work, however (ibid.: 69), the message is dated 1741 by mistake).

${ }^{3}$ The originals of these letters, to my knowledge, were once stored in the personal library of the late M. G. Nurmagomedov from the Arakani village of the Untsukulskij district of Dagestan. However, the present whereabouts of these documents are unknown. Unfortunately, the photocopies of the letters, made from the originals in the early 1990-s, are of very low quality and cannot be reproduced here.

${ }^{4}$ The southern part of the Shamilskij district.
} 


\section{TRANSLATION}

May peace be upon you, the mercy of Allah Almighty and His blessing! From the poor slave [of God], ${ }^{5}$ which is [Ibrahim] ${ }^{6}$, son of Haji of Urada (Uradi); as well as, from the commander ${ }^{7}$ by the name of Den'ga (Dinka) ${ }^{8}$ as well as from the other great men from Tindi (Tindal, Avar ТІиндал) ${ }^{9}$ a Message to the great men, scholars and heads, residents of such [Avar] districts as: Baklulal (Avar Бакълъулал), ${ }^{10}$ Andia (Andal; Avar ГІандал), Botlikh (Balkhal; Avar Балъхъал), ${ }^{12}$ and Untsukul (Ansal ?). ${ }^{13}$

May Allah Almighty strengthen Islam-both through us and through them! May He help us and them against the unfaithful tribe! Amen.

And further.

${ }^{5}$ The word "slave" (Arabic 'abd, Avar лazz), used by Ibrahim-efendi of Urada just as a sign of self-abasement, of personal modesty, later led to the gossips that this figure descended from the slave class.

${ }^{6}$ Ibrahim of Urada made his pilgrimage to Mecca and Medina between 1748 and 1750, and only after that he began to wear the honorary title of haji (see Aytberov 2012: 152, 153).

${ }^{7}$ The Avars used both a Georgian word of Persian origin, beladi (from balad), and the purely Avar tsevexan (цевехван), "leader" in the sense of "commander" or "commander of the army".

${ }^{8}$ A popular name in Western Avaristan. The offsprings of this Den'gi were known in the next century as a blood-related community defeated by the murids of Imam Shamil.

${ }^{9}$ Tindi $($ Тиндиб) is a community in the western part of Avaristan located in the southern part of the current Tsumadinskij district of the Republic of Dagestan. At the end of the 18th century the Tindi "army" consisted of approximately 1500 active soldiers who could have been involved in attacks on Georgia (see Gamrekeli 1980: 173).

${ }^{10}$ The part of the modern Gumbetovskij district of the Republic of Dagestan, which adjoins Chechnya. At the end of the 18th century there was a Baklulal "army" of 1500 active soldiers who attacked Georgia (see Gamrekeli, ibid.).

"An association, which consisted of several relatively populous communities located on the territory of the modern Botlikhskij district of the Republic of Dagestan. At the end of the 18 th century, around 2000 soldiers from here actively participated in attacks against Georgia.

${ }^{12}$ This, most likely, is not just the large village of Botlikh, but the entire "society" of Tekhnutsal with its centre in Botlikh. At the end of the 18th century, about 2000 local warriors were committing incursions into Georgia.

${ }^{13}$ This is a traditionally militant community, considered subordinate to the shamkhals who resided in Tarki. It consisted of several large settlements located on the territory of the present Untsukul district of the Republic of Dagestan. At the end of the 18th century, there were approximately 4000 active warriors who participated in the attacks on Georgia. It is possible, however, that this was not Untsukul, but Ansalt, an Avar settlement in Botlikhskij district. 
We ask you, as noble people, to dress with your best garments and, in this form, to prepare then to advance against the infidels, ${ }^{14}$ making an appropriate effort here. That is required by the courage that Allah has bestowed upon you, and your brilliant bravery, which was acquired in the same way.

We have now learned that the most convenient moment has come. For that reason, we have separated ourselves from other people and began [to send messages] in different directions. We did so to collect troops.

It is imperative that [you] set off this month-on the twenty-second or the twenty-third. ${ }^{15}$ Do not expect that there will be another convenient time for [you to set off]. No one will see that again.

We swear by Allah that if you knew the true situation of the infidels in which they are now, as much as we know it, then you would hurry toward us.

Power and might are only through Allah, the Highest and the Great. What a wonderful patron $\mathrm{He}$ is, what a fine defender! It is enough for us that there is Allah. What a wonderful helper He is! Peace be [upon you]!

\section{LETTER II}

The document is written with reed, black ink, in naskh by Ibrahim-efendi on a sheet $(19.2 \times 12 \mathrm{~cm})$ of white factory paper of Western European production. The number of the lines is 16 . On the margins of the Message there are excerpts (from the Kamus dictionary and the works of Ibn Hajar al-Askalani, etc.) written in Arabic.

\footnotetext{
${ }^{14}$ Two important points should be noted here: a) in the II letter that follows, Ibrahimefendi calls the enemies of Dagestan răfidīs, that is, Iranian Shiites, with a hint of "extreme Shiites" (Гulāt); b) under the influence of the realities of the late $15^{\text {th-17th }}$ centuries, as well as the propaganda, which was carried out by the Ottoman elites, Dagestani scholars of the 17th-18th centuries declared Shiites (meaning the Kyzylbashes) as "infidels", i.e. not Muslims, whose killing would not be a sin. Therefore, it is certain that in this part of the text, the authors are talking about the soldiers of Nadir Shah Afshar, although among them there were many Afghans and Central Asian Turks, Sunnis par excellance (Aytberov 1996: $87,88)$.

${ }^{15}$ Presumably, the 22nd and the 23 rd of the Jumāda al-thāni month of 1154, which corresponds to September 5-6, 1741 (see Aytberov 2012: 95, 97, 101).
} 


\section{TRANSLATION}

From the troops of the Gidatlians ${ }^{16}$ and from the [population] of Andalal district $^{17}$ (Avar ГІандалал) a message to the young people of Karakh $^{18}$ (Avar Къаралал).

May peace be upon you, the Mercy of Allah and His blessing!

May Allah Almighty deliver us from the possibility for the enemies to defeat us!

Amen.

And further.

Until when will you, the Karakhis, portray yourselves as clever people and, at the same time, show laziness in the matter of setting off against the obvious enemy? ${ }^{19}$ Do you really believe you will be left to sleep on the beds of your wives, after the heretics $\left(r a \bar{f} i d_{\bar{\imath}}\right)$ defeat the rest of the Dagestanis?

If in your hearts there is even a drop of temper, then set off against these heretics. Hurry up, oh Karakhis, because those who do not show mercy for others now, will not be sorry later!

Yes, one more thing: there was a battle here in which three hundred silly Dagestanis took part, and then there was their flight ${ }^{20}$ from the enemy. That, however, does not mean anything. Those Dagestanis saw little harm. ${ }^{21}$

${ }^{16}$ According to an official Avar document, dated 1828, there were about 4000 households in Gidatl, although there are other estimations as well (Aytberov 2012: 13, 14).

${ }^{17}$ The territory with the Avar population, corresponding to the southern part of the modern Gunib district of the Republic of Dagestan. At the end of the 18th century, around 4000 active warriors from Andalalian villages were attacking Georgia (see Gamrekeli 1980: 173). In the conditions of the Caucasian War and the resulting Russian blockade of the Avar zone of the Mountainous Dagestan, there were around 2300 households in the three main settlements of Andalal by 1843 (see Xašaev 1961: 16, 17).

${ }^{18}$ The northern part of the Charodinskij district of the Republic of Dagestan. At the end of the 18th century, there were 2000 active warriors in Karakh who committed incursions into Georgia (see Gamrekeli, ibid.).

${ }^{19}$ The point here is that shortly before receiving the letter from the Gidatlians and Andalalians the addressees signed a paper about submitting to Nadir Shah (see Aytberov 2011: 89-91).

${ }^{20}$ Meaning "retreat", Old Avar лъути.

${ }^{21}$ Ibrahim-efendi probably speaks about volunteers, brave and valiant people, who were nevertheless not knowledgeable about military concepts, maneuvers, tricks, etc. 
Do not believe, oh Karakhis, the words of devils in human form, gossiping that the mentioned circumstance held the true believers from the battle, or that it slowed their setting off from [the camp]!

You need to hurry and rush to set off. You should also deliver food [to our camp], collecting it from those places that are near you. Peace be [upon you]!

\section{LETTER III}

This letter is also written with the same technique by Ibrahim of Urada on a sheet $(15 \times 9 \mathrm{~cm})$ of white factory paper. Perhaps, this one is written a little earlier than the previous two. The number of the lines is 11.

\section{TRANSLATION}

May peace be upon you, the mercy of Allah and His blessing!

From the Gidatl warriors, a message to those who stayed [at home].

May Allah protect us from the possible victory of the enemy!

Amen!

And further.

You, those who stayed [at home], are obliged: first, to build, more precisely, to revive, the fortress wall (sūr) of the Tidib village; secondly, to hide food products, those which will be possible for you to hide.

Further. The population of the Andalal district has shown negligence towards [our] enemies. That happened after the designated enemy defeated a part of the Andalalis.

We, the Gidatlis in the [military camp], will now apply our efforts—if, of course, Allah wishes so-to gather all the Muslims [Sunnis] and drag them out, then, to a real war. We will also try, of course, to the best of our ability to call to peace our enemies known to you. Otherwise, our turn [to suffer?] will reach us too. Hence you, before taking a certain step, determine the place where you will put your step.

To conclude, generally: do not be afraid of the enemy, but at the same time, issue prohibitions on [communication] with them. And in general, do not be careless!

\section{CONCLUSION}

With the efforts of Ibrahim(-efendi) of Urada and his companions, several thousand well-trained Avar warriors, with whom there were representa- 
tives of other peoples of Dagestan, were recruited in 1741 on the southern and eastern borders of Avaristan against the Iranian army headed personally by Nadir Shah Afshar. At the same time, one cannot ignore the fact that by the fall of 1741 a large part of the Avars-peaceful peasants, townspeople and professional soldiers-were afraid of the victorious Iranians. It was also important that the Dagestani commanders, among which Ibrahim of Urada, thought until the very last minute about solving the matter with the Iranians in 1741 through peace without a battle. However, they failed to do so. Most likely, the fighting began on September 12, 1741 along a front line of several tens of kilometers. Troops of all the Avar communities, which are named in the letters published here, took part in the battles and so did the troops of other Avar social and political associations, side by side with other Dagestanis - all in all, according to the Georgian sources (Gamrekeli 1980: 174), around 11,000 warriors.

Nadir Shah advanced from the mountain plateau of Turchi-dag (Avar ЧІалда-мегІер) in the direction of Andalal against the Avar settlements of Obokh and Megeb, which the Iranians captured, destroyed and burned. Then, Nadir Shah, returned to Turchi-dag and sent his well-trained troops to the Andalal settlement of Sogratl (Сугъралъ) where one of the main military camps of the Dagestanis was located. Ibrahim-efendi was in that camp then. After two days of fierce fighting in which the Untsukuli warriors who came from the depths of Georgia (near Gori) took an active part, the Iranians began to retreat in panic. They were going in the direction of Turchi-dag where Nadir Shah had stopped. It should be noted that other Dagestani troops were also attacking the Iranians here as part of the overall plan of the battle.

Nadir Shah saw the troops of the Avar Khanate swooping on his camp. Angered by the defeat of his army, he jumped ahead and called upon any of the Dagestanis challenging them for a one on one fight. He announced the conditions in Turkish promising that none of his guards would interfere in the duel. From the ranks of elite Avars led at that time by the famous mountain commander Murtazali of Kazikumukh, a Laki by origin, came out a free warrior (ozden) born in a small town called Khunzakh. According to the legendary stories of Khunzakh, his name was Xajimaxama Korgolilav. He struck the ruler of Iran with such a powerful blow that the latter staggered and released his sabre, an Indian trophy 
taken from the palace of the Great Moguls in Delhi. That sabre is now kept in the Dagestan State Museum. It was purchased from someone of Khunzakh origin whose ancestors had acquired it after the treasury of the Khans of Avaristan was ruined, which happened in 1834 when Imam Khamzat was installed there.

\section{BIBLIOGRAPHY}

Aytberov, T. M. (1996), History of the Avar Wars in Transcaucasia, Makhachkala (in Avar).

-(2011), Nadir-šax Afšar i dagestancy v 1741 g., Makhachkala.

_-(2012), Ibraxim-xadži Uradinskij: novye stranicy biografii, Makhachkala.

Gadžiev, V. G (1996), Razgrom Nadir-šaxa v Dagestane, Makhachkala.

Gamrekeli, V. N. (1980), Mežkavkazskie političeskie i torgovye svyazy Vostočnoj Gruzii: konec 6o- $x$ - načalo go-x godov XVIII $v$., vypusk 1 , Tbilisi.

Sotavov, N. A. (1991), Severnyj Kavkaz v russko-iranskix i russko-tureckix otnošeniyax v XVIII v., Moskva.

Xašaev, X.-M. (1961), Obščestvennyj stroj Dagestana v XIXv., Moskva. 